\title{
The Impact of Knowledge-Based Economy on Growth Performance: Evidence from MENA Countries
}

\author{
Sajjad Barkhordari ${ }^{1} \cdot$ Maryam Fattahi $^{2}$. \\ Naser Ali Azimi ${ }^{3}$
}

Received: 5 April 2017 / Accepted: 23 January 2018 / Published online: 13 February 2018

(C) The Author(s) 2018. This article is an open access publication

\begin{abstract}
The aim of this paper is to examine the empirical relationship between the knowledge-based economy and economic growth in MENA countries. We are interested in identifying pillars linked with the transition to a knowledge-based economy that is related to growth performance. We used a growth model in Barro and Sala-i-Martin framework (1995) for the period of 2010-2015. It includes a panel data set that consisted the annual economic growth rate for selected MENA countries and, within the theoretical and empirical framework, applied the four indicators used for identifying the situation of the knowledgebased economy. The empirical results obtained using the generalized method of moments dynamic panel indicates institutions, human capital and research, infrastructure, and business sophistication to be the pillars of knowledge-based economy that influence a significant and positive economic growth in MENA countries. We suggest that governments in this region should consider the knowledge-related policies for accelerating transiting to the knowledgebased economy and improving economic performance.
\end{abstract}

Keywords Convergence - Dynamic panel $\cdot$ Generalized method of moments · Growth performance $\cdot$ Knowledge-based economy $\cdot$ MENA region

\section{Highlights:}

- We use a dynamic GMM panel model for analysis of conditional convergence in MENA region.

- We assess the effects of knowledge-based economy indices on economic performance in MENA region.

- The institutional structure and human capital and research have positive effects on growth performance in MENA region.

- The effect of infrastructure and business sophistication on economic growth in MENA countries.

Sajjad Barkhordari

barkhordari@ut.ac.ir; sajadbarkhordari@gmail.com

1 Faculty of Economics, University of Tehran, Tehran, Iran

2 Faculty of Economics, Tarbiat Modares University, Tehran, Iran

3 Department of Economics of Science and Technology, National Research Institute for Science Policy (NRISP), Tehran, Iran 
JEL Classifications $\mathrm{C} 33 \cdot \mathrm{O} 38 \cdot \mathrm{O} 57 \cdot \mathrm{P} 41$

\section{Introduction}

Nowadays, the world's economies are rapidly transiting towards being more knowledge-based, and supporting knowledge is a vital factor of economic growth. The recent trend of globalization has led all continents, regions, or countries to be actively involved in the global economy so that the competition is the main factor in progress. Knowledge-based economies provide an environment where competition is vital. The knowledge-based economies are an economic development model which emerged in the late 1990s in the Organization for Economic Co-operation and Development (OECD) and World Bank reports (Bank 2007; OECD 1996). Chen and Dahlman (2005) reported that a knowledge-based economy is built upon four pillars: First, it requires an economic and institutional framework that provides incentives for the efficient creation, the dissemination, and the use of knowledge to promote growth and increase welfare. Second, it needs an educated and skilled population that can create knowledge and use it. Third, innovation systems that can tap into the growing stock of global knowledge, adapt it to local needs, and transform it into products valued by markets are necessary. Finally, a dynamic information infrastructure is required that can facilitate effective communication and processing of information.

The Middle East and North Africa (MENA) is an economically diverse region that includes countries with a common heritage, at various stages of economic development and with vastly different endowments of natural resources. Despite undertaking economic reforms in many of countries in this region, the region's economic performance is below its full potential (Abed and Davoodi 2003). Since World War II, economic growth in the MENA region has mainly been driven by the exploitation and exportation of natural resources, especially oil. The boom in oil prices lead MENA countries to enjoy a high economic growth rate in the 1970s and 1980s, and the countries in this region invested heavily in ambitious development projects, education, ICT, and public health (World Bank 2016). In recent years, MENA countries have heavily invested in the knowledge economy.

The Global Innovation Index (GII) score for Iran was 28.41 in 2011 and has increased to 30.52 in 2016, while that for human capital and research for Iran was 32.2 in 2011 and has increased to 39.5 in 2016. Other countries of the MENA region such as Saudi Arabia, Qatar, and the United Arab Emirates have recognized the main role of knowledge in economic growth and heavily invested in the four knowledgebased economy pillars (WIPO 2016). Future economic growth in the MENA countries, as in other regions such as OECD, will depend on knowledge.

The economic growth in the MENA region has decreased in recent years, from $5.1 \%$ in 2010 to $3.08 \%$ in 2015. Also, the growth of per capita GDP in this region has decreased and fell to $1.22 \%$ in 2015 . However, the economic growth of this region is highly correlated with oil exports, but oil income cannot increase the economic growth of this region. Therefore, it is necessary to transit to a knowledge-based economy in the MENA countries.

Endogenous growth models stress the presence of differences in per capita income across countries. Theoretically, these models emphasize mechanisms which generate 
divergence across economies. Therefore, estimating the convergence equation has become increasingly popular as the two types of convergence hypotheses include absolute and conditional convergence. The test of convergence hypothesis was considered to constitute main empirical research about economic growth in different economic areas (Fung 2009; Jalilian et al. 2007; Klasen 2002; Miller and Upadhyay 2002; Murthy and Chien 1997; Roe 2003). Economic growth in the MENA countries is different from that of other regions, and investment for transiting to a knowledge-based economy is an important issue in MENA region. Therefore, a study of economic growth in this region which focuses on the knowledge-based economy literature can help policy makers. Hence, in this context, the aim of this paper is to investigate empirical policies and investments linked to the transition to a knowledge-based economy such as the institutional framework, human capital and research, public and private infrastructure, and business sophistication are which related to higher economic growth rates and economic welfare in MENA countries. We use the generalized method of moments (GMM) dynamic panel estimators that provide a more advanced econometric technique, which has recently been used in the growth literature as an alternative to cross-sectional estimators ((Badinger et al. 2004; Bond et al. 2001; Christopoulos and Tsionas 2004; Habibullah and Eng 2006; Kumar et al. 2013) The advantage of the GMM method is that it takes care of the econometric problems caused by unobserved country-specific effects and endogeneity of the independent variables in laggeddependent variable models such as economic growth models. The inclusion of both cross-country and time series data introduces additional information about the change over time in growth and its determinants. Therefore, this method helps us get more precise results.

This paper then proceeds as follows. The second section outlines some of the theoretical and empirical frameworks for addressing the concept of convergence in economic growth models and the role of knowledge-based economy pillars in economic growth. The third section concerns the empirical model, data, and the methodology used to estimate the empirical model, while the fourth section summarizes the empirical results, and the fifth section provides the conclusions and policy implications.

\section{Theoretical and Empirical Evidence}

Since the pioneering works of Solow (1956) and Swan (1956), much of the literature growth such as Barro (1991), Sala-i-Martin (1996), Islam (2003), and Mankiw et al. (1992) has focused on convergence theory. In convergence theory, two definitions have emerged: absolute convergence and conditional convergence and the various empirical studies fall into these two categories, namely as a test of unconditional (absolute) and conditional convergence. Absolute convergence assumes that all regions (countries) are intrinsically the same apart from their initial capital/labor ratio. Regions with a lower initial income have a lower capital/labor ratio than the long-run value, and so they have higher rates of return. This means that poorer regions will grow faster to decrease their disparity with richer regions.

Conditional convergence recognizes disparities among regions in various respects and assumes that each region will converge towards its own steady-state level. To test 
the hypothesis of conditional convergence, we need a set of variables which differentiate regions. According to the economic literature on growth and convergence (Islam 2003; Sala-i-Martin and Barro 1995), this set of variables includes physical capital, human capital, public consumption to GDP ratio, investment to GDP ratio, and trade. In addition, the growth literature verifies that conditioning factors also include a capacity of absorbing technology (Abramovitz 1986), the quality of human capital (Mankiw et al. 1992; Balcerzak and Pietrzak 2016; Schultz 2007), R\&D infrastructure, and inventiveness (Aghion and Howitt 1990; Grossman and Helpman 1994; Huallacháin 2007).

New growth theories have shown that knowledge is an especially valuable factor in production, taking into account the unique characteristics of information and its ability to be passed from the user without losing its usefulness. Investments in equipment embodying new technological developments and in education, invention, and related knowledge-enhancing activities are all factors that increase capital as human capital. Technological progress makes it possible to extract greater value from limited resources to sustain economic growth (Romer 1986; Romer 1990; Lucas 1988; Acemoglu 2008). A knowledge-based economy has three essential elements that include skilled labor, incentive, and innovation. Katz et al. (1999) demonstrated that the number of jobs and the wage rates of the better educated have grown more rapidly compared with those of unskilled labor. The findings of Levy and Murnane (1996) indicated that the employment of skilled labor is positively correlated with capital intensity and the installation of new technologies. According to these findings, inter-regional variation, in workforce skills, might correlate with regional economic performance. Fagerberg and Verspagen (2003) identified a strengthening relationship between incentives and national growth in a knowledge-based economy.

The conditional convergence hypothesis has been verified by many studies. Barro and Martin (2004) and Bloom et al. (2002) used various data sets and econometric techniques. Traditional control variables that have a significant impact on growth include initial GDP, investment, government expenditure, and openness to trade. There is growing evidence also on the importance of other variables for growth. We review the empirical literature related to economic growth in four groups on the basis of KBE indices. These groups include (a) institutions: political environment, regulatory environment, and business environment; (b) human capital and research: education, tertiary education, and research and development; (c) infrastructure: ICTs, general infrastructure, and ecological sustainability; and (d) business sophistication: knowledge workers, innovation linkages, and knowledge absorption.

In the first group, cross-country empirical studies have investigated the link between the status of institutions and differences in growth rates. Barro and Sala-i-Martin (1994) found that political instability has a statistically negative impact on growth. Kaufmann et al. (1999) demonstrated a strong relationship between the quality of governance and GDP per capita. Cooray (2009), Grogan and Moers (2001), Havrylyshyn and van Rooden (2003), and Kurtz and Schrank (2007) confirmed the importance of the institutional framework for economic growth in transition countries. Jalilian et al. (2007) showed a strong causal link between regulatory quality and economic performance in developing countries. Slesman et al. (2015) have verified that institutional quality has a significantly positive effect on growth in Islamic countries. The findings of Flachaire et al. (2014) indicate that economic institutions have a direct 
impact on growth rate. These studies support evidence of a relationship between the quality of institutions and economic growth. This means that countries with better quality institutions will invest more, which leads to higher growth economic rates.

In the second group of studies, human capital and research are included in growth as knowledge, skills, competencies, and other attributes embodied in individuals (Heath 2001). Many studies such as those by Bassanini et al. (2000), Lee et al. (1994), Lucas Jr (2015), Mankiw et al. (1992), and Wolf (2002) have focused on the role of human capital in growth. Fleisher et al. (2010) and Sab and Smith (2001) find a strong positive correlation between human capital and economic growth in 100 countries. Chapsa et al. (2015) showed that there is a positive and significant relationship between human capital and growth in EU-15 countries, while Cardoso and Pentecost (2011) found that both secondary and higher levels of education as proxies for human capital had a significant positive effect on regional growth in Portuguese regions. The results of Qadri and Waheed (2013) indicated that human capital either resists income divergence across middle and high-income nations or supports conditional convergence. The empirical studies in this group at both micro and macro levels suggest that education and skills development provide new opportunities to developing and adopting new technology. Indeed, in the case of R\&D, there seems to be a stronger consensus that it may have a persistent effect on growth; that is, higher R\&D expenditure would be associated with permanently higher growth rates (Akcali and Sismanoglu 2015; Guellec and De La Potterie 2002). Therefore, human capital and research are the leading factors in raising productivity because they facilitate knowledge spillovers and the adaptation of new technologies to economic growth (Carlsson et al. 2009; Chun-Chien and Chih-Hai 2008; Harris 2001).

In the third group of studies, a wide consensus exists that infrastructure is necessary for the development at the macro and micro levels. Infrastructure has been seen to increase productivity and attract business activity by lowering transport and production costs and facilitating market access. Banerjee et al. (2012), Boopen (2006), and Torero et al. (2002) showed a positive causal link between telecommunication infrastructure and economic growth in developing countries. Canning and Pedroni (2004) presented clear evidence that infrastructure, in the vast majority of cases, does induce long-term growth effects. Also, they found a great deal of variation in the results across individual countries. Duggal et al. (2007) concluded that public capital has the potential to generate a return to scale at the aggregate level, thereby implying a permanent increase in economic growth. Égert et al. (2009) revealed the positive impact of infrastructure investment on growth, showing that this effect varies across countries and sectors in OECD countries. Palei (2015) argued that infrastructure factors allow countries to be more successful in raising income levels.

Finally, in the fourth group of studies, knowledge workers, the innovation linkage, and knowledge absorption are all determinant factors of business sophistication, and they accelerate the transition to a knowledge-based economy. Balkyte and Tvaronavičiene (2010) and Pyöriä (2005) have emphasized the abilities of knowledge workers to act as an interface between new technology and human interactions. Glaeser (2000) and Raspe and Van Oort (2008) confirm the importance of knowledge work and knowledge worker as the engines of regional economic growth. Badinger and Tondl (2003) and Małgorzata Runiewicz-Wardyn (2008) verified that education and learning are important factors for narrowing 
knowledge absorption and innovation. Wintjes and Hollanders (2010) showed that the impact of knowledge and technology factors on GDP per capita varies across different regions of EU, while Abreu et al. (2008) investigated that absorptive capacity at the firm level is the major determinants of regional innovation performance. The results of Malgorzata Runiewicz-Wardyn (2013) study indicate that technological change in regions of the EU is dependent on social capital and knowledge transfer, and the accumulation of embodied technology capital. Business sophistication is, therefore, an important factor in the transition towards a knowledge economy and accessing economic growth. According to the theoretical and empirical literature review, the status of a country's transition to a knowledgebased economy can describe differences in economic growth. In recent decades, the MENA economies are readying to transit to a knowledge-based economy. This transition to a knowledge-based economy might decrease the disparities in economic growth in MENA countries. With attention to the transition of MENA countries to a knowledge-based economy, in this paper, we test the hypothesis of conditional convergence considering knowledge-based economy indices. The previous studies focused on developed countries, and the role of knowledge-based economy on economic performance in developing countries such as MENA countries less has been studied. The contributions of this paper are (a) the test of convergence in economic growth in MENA countries, (b) the analysis of the knowledge-based economy in this region, and (c) recognizing main pillars of the knowledge-based economy in economic performance in MENA region.

\section{Empirical Model and Data}

In order to survey the regional convergence in panel data regressions, we use the empirical framework suggested by Roubini and Sala-i-Martin (1995). This framework relates real per capita growth rate to initial levels of state variables, such as the stock of physical capital and stock of human capital, as well as to control variables. The control variables determine the steady-state level of output in the Solow-Swan model. Following Sala-i-Martin and Barro (1995), we assume that a higher level of initial per capita GDP indicates a greater stock of physical per capita. We also assume that the lagged value of per capita output in the short run reflects the initial stock of human capital (Cohen and Soto 2007). We can write the model of output per capita growth rate as a dynamic panel model as follows:

$$
\begin{gathered}
\ln \left(y_{i, t}\right)-\ln \left(y_{i, t-1}\right)=\alpha \ln \left(y_{i, t-1}\right)+\ln \left(Z_{i, t}\right) \beta+\eta_{i}+\xi_{t}+\varepsilon_{i, t} \\
\ln y_{i, t}=\lambda \ln \left(y_{i, t-1}\right)+\ln \left(Z_{i, t}\right) \beta+\eta_{i}+\xi_{t}+\varepsilon_{i, t} \\
\lambda=1+\alpha
\end{gathered}
$$

where $y_{i, t}$ is per capita gross domestic product (GDP) in MENA countries ${ }^{1} i(i=1,2$,

\footnotetext{
${ }^{1}$ MENA region include 21 countries: Algeria, Bahrain, Djibouti, Egypt, Iran, Iraq, Israel, Jordan, Kuwait, Lebanon, Libya, Malta, Morocco, Oman, Qatar, Saudi Arabia, Syrian, Tunisia, United Emirate Arab, Gaza, Yemen. In this paper, because of incomplete data of Djibouti, Iraq, Libya, Syrian, and Gaza, we used the data of 16 countries.
} 
$\ldots, 16)$ during the period $t(t=2010-2015),{ }^{2} y_{i, t-1}$ is the (initial) per capita GDP in country $i$ during period $t-1, Z_{i, t}$ is a row vector of control variables in country in during period $t, \eta_{i}$ is a country-specific effect, $\xi_{t}$ is a period-specific effect common to all countries, and $\varepsilon_{i, t}$ is the stochastic error term. The log-linear functional form is applied in order to reduce likely heteroscedasticity.

Barro and Martin (2004) suggest the measures of market distortions, domestic investment, and the degree of economic openness, financial development, and political instability as possible control variables in the growth model. According to Cohen and Soto (2007), it is assumed that variations in the measures of market distortions, financial development, and political instability are small during the relatively short time span. On the basis of this assumption, the effects of these variables will not be revealed in the time dimension but will appear in the cross-country dimension. Then, these effects will be embodied in the country-specific effect, which appears as $\eta_{i}$ in Eq. 2.

In this paper, we use three control variables suggested by Barro and Martin (2004), which can be viewed as determinant factors in the economic growth in MENA countries. These three variables are trade openness (OPEN), investment (INV), and government consumption (GOV). OPEN is included to predict the positive contribution of the degree of the openness to economic growth, which is applied in natural logarithm form. INV is the ratio of the real gross fixed capital formation to real GDP that represents the public and private investment. The findings of theoretical and empirical studies verified a positive effect of the investment on economic growth. GOV is the natural logarithm of the ratio of government consumption to GDP as a proxy of the role of government in making of macroeconomic policies and their quality on economic growth. We extracted the data from the World Bank official website.

In order to achieve the main purpose of this paper, we estimate the three control variables with knowledge-based economy (KBE) indicators. Various measures are used in the literature as proxies for the $\mathrm{KBE}$, and in this study, we use four indicators, namely human capital (HC), institutional regime (INS), infrastructure (INF), and business sophistication (BS) that are measured on a $0-100$ score by WIPO. The summary of descriptive statistics and data sources is presented in Table 1. We extracted the data from World Bank data series and World Intellectual Property Organization (WIPO) reports titled GII for the period of 2010-2015. Also, we used the log of data, except GDP per capita growth. The correlation matrix in Table 2 presents some facts about the economies of MENA countries.

The growth regression as Eq. 1 poses some challenges for estimation. The first is the presence of an unobserved period and country-specific effects. While the inclusion of period-specific dummy variables can account for the time effects, the common methods of dealing with country-specific effects are inappropriate given the dynamic nature of the regression model. The second challenge is that most explanatory variables are likely to be jointly endogenous with economic growth. On the panel data literature, given its dynamic nature, the aforementioned problems lead the ordinary least square (OLS), the fixed effects (FE), and the random effects (RE) approach to produce biased and inconsistent estimates with small samples. It is worth emphasizing that only if $T \rightarrow \infty$

\footnotetext{
${ }^{2}$ There are almost complete data of indices for knowledge-based economy, especially MENA countries, since 2010. Thus, we have to use the data over 2010-2015.
} 
Table 1 Summary of descriptive statistics and data sources

\begin{tabular}{|c|c|c|c|c|c|c|c|c|}
\hline Variable & Obs. & Mean & SD & Median & Min & Max & Description & $\begin{array}{l}\mathrm{D} \text { a } \mathrm{t} \mathrm{a} \\
\text { source }\end{array}$ \\
\hline $\begin{array}{l}\text { GDP per capita } \\
\text { growth }\end{array}$ & 96 & -0.43 & 6.03 & - & -29.83 & 6.79 & $\begin{array}{l}\text { Average annual growth } \\
\text { rate over } 6 \text { years }\end{array}$ & WB \\
\hline Log (INV) & 96 & 3.12 & 0.47 & 3.21 & 0.54 & 3.82 & Log of investment & WB \\
\hline $\log (\mathrm{OPEN})$ & 96 & 4.52 & 0.49 & 4.58 & 3.48 & 5.78 & Log of trade openness & WB \\
\hline $\log (\mathrm{GOV})$ & 96 & 2.79 & 0.27 & 2.88 & 2.27 & 3.38 & $\begin{array}{l}\text { Log of government } \\
\text { consumption }\end{array}$ & WB \\
\hline $\log (\mathrm{INS})$ & 96 & 4.01 & 0.34 & 4.09 & 1.66 & 4.43 & Log of institution score & WIPO \\
\hline $\log (\mathrm{HC})$ & 96 & 3.59 & 0.28 & 3.59 & 2.67 & 4.24 & $\begin{array}{l}\text { Log of human capital } \\
\text { and research score }\end{array}$ & WIPO \\
\hline $\log (\mathrm{INF})$ & 96 & 3.55 & 0.29 & 3.56 & 2.73 & 4.03 & Log of infrastructure score & WIPO \\
\hline $\log (B S)$ & 96 & 3.51 & 0.36 & 3.58 & 2.4 & 4.17 & $\begin{array}{l}\text { Log of business } \\
\text { sophistication score }\end{array}$ & WIPO \\
\hline
\end{tabular}

WB World Bank, WIPO World Intellectual Property Organization

can the above approaches be unbiased and consistent (Baltagi 2008). With attention to the fact that data in this study covers a moderate number of countries $N$ over a moderate size $T$ and $T$ is not very small relative to $N$, we use the GMM estimators introduced by Arellano and Bond (1991). We can control the unobserved effects and jointly endogenous problems because the Arellano and Bond estimator is based, first, on differencing regressions or instruments to control for unobserved effects and, second, on using observations of explanatory and lag of the dependent variable as instruments that are called internal instruments.

We exploit the GMM-DIFF procedure of Arellano and Bond (1991). So, first differencing the dynamic model (1), we get

$$
\Delta \ln y_{i t}=\lambda \Delta \ln y_{i, t-1}+\Delta \ln \left(Z_{i t}\right) \beta+\Delta \eta_{i}+\Delta \xi_{t}+\Delta \varepsilon_{i, t}
$$

Table 2 Correlation among variables

\begin{tabular}{|c|c|c|c|c|c|c|c|c|c|}
\hline & Growth & $\log \left(\operatorname{gdp}_{0}\right)$ & $\begin{array}{l}\text { Log } \\
(\text { INV) }\end{array}$ & $\begin{array}{l}\log \\
(\mathrm{OPEN})\end{array}$ & $\begin{array}{l}\text { Log } \\
(\mathrm{GOV})\end{array}$ & $\begin{array}{l}\log \\
\text { (INS) }\end{array}$ & $\begin{array}{l}\text { Log } \\
(\mathrm{HC})\end{array}$ & $\begin{array}{l}\text { Log } \\
\text { (INF) }\end{array}$ & $\begin{array}{l}\log \\
\text { (BS) }\end{array}$ \\
\hline Growth & 1 & & & & & & & & \\
\hline $\log \left(g_{d p}\right)$ & 0.26 & 1 & & & & & & & \\
\hline $\log (\mathrm{INV})$ & 0.55 & 0.27 & 1 & & & & & & \\
\hline $\log (\mathrm{OPEN})$ & 0.26 & 0.43 & 0.22 & 1 & & & & & \\
\hline $\log (\mathrm{GOV})$ & 0.14 & 0.08 & 0.26 & 0.21 & 1 & & & & \\
\hline Log (INS) & 0.35 & 0.67 & 0.31 & 0.74 & 0.35 & 1 & & & \\
\hline $\log (\mathrm{HC})$ & 0.36 & 0.47 & 0.39 & 0.35 & 0.05 & 0.53 & 1 & & \\
\hline $\log (\mathrm{INF})$ & 0.40 & 0.68 & 0.36 & 0.42 & 0.26 & 0.63 & 0.52 & 1 & \\
\hline $\log (\mathrm{BS})$ & 0.14 & 0.54 & 0.16 & 0.46 & 0.03 & 0.57 & 0.71 & 0.56 & 1 \\
\hline
\end{tabular}

The variables are averaged over 6-year periods 
where $\Delta=0, \Delta \xi_{t}=\xi$ (constant), and $\Delta$ denotes the first difference. Since the Arellano and Bond GMM-DIFF estimation results are identical for both specifications, we report only the results for model (1). It is noted the GMM-DIFF estimators work well for smallest sample size, i.e., $N=10$ and $T=3$; thus, the GMM-DIFF estimators for $N=16$ and $T=6$ in this paper are not biased (Santos and Barrios 2011).

The GMM estimator is consistent only if the lagged values of the explanatory variables are valid instruments. In the econometrics of the panel data literature, the validity of the moment conditions implied by dynamic panel data is commonly tested using the conventional GMM test of over-identifying restrictions of which the Sargan test is widely used. The Sargan test assesses the validity of the instruments in the model. This test is as follows:

$$
S=(V \dot{Z})\left(\dot{Z}^{\prime} V \dot{V} Z\right)\left(\dot{Z}^{\prime}\right)
$$

where $V$ is a vector of estimated residuals and $Z$ is the matrix instruments. The null hypothesis of this test is "the instruments as a group are exogenous" $\left[E\left(\dot{Z}^{\prime} V\right)=0\right]$. The Sargan test has chi-squared $\left(\chi^{2}\right)$ distribution under the null hypothesis with the degrees of freedom equal to the number of moment conditions minus the number of parameters to be estimated (Verbeek 2008).

\section{Empirical Results}

The GMM-DIFF robust two-step estimation results are represented in Tables 3, 4, 5, 6, and 7. We report the results under two assumptions: first, the impact of the three control variables including INV, GOV, and OPEN, without considering the KBE indicators; second, the impact of the three control variables, considering the KBE indicators individually. The Hansen statistic of over-identifying restrictions tests the hypothesis (Sargan test) that the instruments are not correlated with the residuals. For all the estimated specifications of the model, we cannot reject the hypothesis that the instruments are valid.

The coefficient of initial GDP in the estimated model is negative and of statistical significance, which shows the existence of conditional convergence in MENA

Table 3 Conditional convergence of economic growth without KBE induces

\begin{tabular}{lcccr}
\hline Explanatory variables & Coefficient & Std. error & $t$-statistic & Prob. \\
\hline Constant & -0.19 & 0.046 & -4.12 & 0.00 \\
GDP initial & -0.003 & 0.0009 & -3.72 & 0.00 \\
INV & 0.019 & 0.008 & 2.39 & 0.02 \\
GOV & 0.02 & 0.0063 & 3.74 & 0.00 \\
Open & 0.023 & 0.0028 & 7.17 & 0.00 \\
$R^{2}$ & 0.19 & & & \\
J-statistic (Sargan test) 1.18 & & Prob. (J-statistic) 0.27 & \\
\hline
\end{tabular}


Table 4 Conditional convergence of economic growth with the human capital and research index

\begin{tabular}{lcccr}
\hline Explanatory variables & Coefficient & Std. error & $t$-statistic & Prob. \\
\hline Constant & -0.25 & 0.063 & -3.98 & 0.00 \\
GDP initial & -0.006 & 0.0004 & -15.16 & 0.00 \\
INV & 0.018 & 0.009 & 1.96 & 0.05 \\
GOV & 0.025 & 0.003 & 6.68 & 0.00 \\
Open & 0.014 & 0.003 & 4.26 & 0.00 \\
HC & 0.029 & 0.009 & 2.95 & 0.00 \\
$R^{2}$ & 0.30 & & & \\
J-statistic (Sargan test) 0.29 & & Prob. (J-statistic) 0.58 & \\
\hline
\end{tabular}

countries. So, the neoclassical hypothesis of conditional convergence in MENA countries is not rejected. This convergence predicts higher growth in response to lower starting per capita when other explanatory variables are held constant. Regarding the control variables, our results are consistent with the empirical and theoretical literature. The signs of the three control variables are positive and significant as expected. As reported in Table 3, the impact of economic openness is higher than for investment and government expenditure on the same steady-state point in the MENA countries.

We insert the KBE indicators individually. The estimated model (Table 4) indicates that $\mathrm{HC}$ is significantly and positively related to economic growth. This finding could be interpreted as showing the main role of human capital in MENA countries. The estimated model (Table 5) indicates that INS induces that economic growth, but this effect is significantly weak. Also, the effect of the institution for KBE is greater than that of other indices. In addition, the effect of INV is positive and significantly weak.

The results of estimated model (Table 6) show that INF is a determinant factor on economic growth convergence in MENA countries. Also, by the inclusion of INF in the model, the speed of convergence is increased. We can conclude that infrastructure for transiting to KBE in MENA countries leads the economic growth of these countries closer to each other.

Table 5 Conditional convergence of economic growth with the institution index

\begin{tabular}{lcccc}
\hline Explanatory variables & Coefficient & Std. error & $t$-statistic & Prob. \\
\hline Constant & -0.18 & 0.063 & -2.89 & 0.00 \\
GDP initial & -0.005 & 0.001 & -3.42 & 0.00 \\
INV & 0.011 & 0.007 & 1.47 & 0.14 \\
GOV & 0.016 & 0.005 & 1.9 & 0.00 \\
Open & 0.018 & 0.004 & 4.59 & 0.00 \\
INS & 0.019 & 0.012 & 1.63 & 0.10 \\
$R^{2}$ & 0.18 & & & \\
J-statistic (Sargan test) 2.24 & & Prob. (J-statistic) 0.13 & \\
\hline
\end{tabular}


Table 6 Conditional convergence of economic growth with the infrastructure index

\begin{tabular}{lcccr}
\hline Explanatory variables & Coefficient & Std. error & $t$-statistic & Prob. \\
\hline Constant & -0.23 & 0.035 & -6.55 & 0.00 \\
GDP initial & -0.015 & 0.001 & -8.41 & 0.00 \\
INV & 0.012 & 0.004 & 2.93 & 0.00 \\
GOV & 0.020 & 0.004 & 4.76 & 0.00 \\
Open & -0.003 & 0.001 & -1.89 & 0.06 \\
INF & 0.073 & 0.007 & 10.54 & 0.00 \\
$R^{2}$ & 0.46 & & & \\
J-statistic (Sargan test) 0.06 & & Prob. (J-statistic) 0.79 & \\
\hline
\end{tabular}

We concentrate on the role of BS in the convergence of economic growth in MENA countries. The estimated model (Table 7) demonstrates that BS has a positive and significant effect on conditional convergence. In addition, the effect of BS is larger than other control variables. Comparing the results reported in Tables 3, 4, 5, 6, and 7, we detect that the KBE indices in MENA countries have positive and significant effects on conditional convergence and increase the speed of convergence.

\section{Conclusion and Policy Implications}

The aim of this study is to estimate and analyze the effects of the knowledge-based economy on the economic growth process in the MENA region. The results reveal that the three control variables of public and private investment, government expenditure, and trade openness have both a positive and significant effect on growth performance, and these results are consistent with empirical and theoretical expectations.

The empirical findings point to the fact that institutions enhance growth performance. The positive effect of institutions on economic growth indicates that the political, regulatory, and business environments, as a subset of the institutional context, play a key role in the transition of the MENA countries towards a knowledge-based

Table 7 Conditional convergence of economic growth with the business sophistication index

\begin{tabular}{lcccr}
\hline Explanatory variables & Coefficient & Std. error & $t$-statistic & Prob. \\
\hline Constant & -0.19 & 0.066 & -2.89 & 0.00 \\
GDP initial & -0.009 & 0.002 & -4.43 & 0.00 \\
INV & 0.023 & 0.015 & 1.52 & 0.13 \\
GOV & 0.018 & 0.004 & 4.12 & 0.00 \\
Open & 0.012 & 0.006 & 1.81 & 0.07 \\
BS & 0.029 & 0.012 & 2.31 & 0.02 \\
$R^{2}$ & 0.26 & & & \\
J-statistic (Sarsgan test) 039 & & Prob. (J-statistic) 0.52 & \\
\hline
\end{tabular}


economy. As an example, the business environment shows a better performance than does the political and regulatory environment for Iran's transition to a knowledge-based economy.

The effect of human capital and research on economic growth is both positive and significant. This means that investment in human capital and research can improve the growth performance of MENA countries. In addition, these results announce that education (including tertiary education), research, and development as a subset of human capital and research are important for accessing high economic growth rate.

Infrastructure plays a determinant role in economic growth. The results of this study signify the positive effect of infrastructure on growth performance. This means that infrastructure provides the necessary conditions for MENA countries transiting to knowledge-based economies. Also, these results indicate that investment in ICT and public infrastructure boosts the infrastructure to develop a knowledge-based economy in this region. One of the serious problems in some MENA countries is the low quality of their infrastructure. For example, Egypt, Iran, and Kuwait are ranked 108, 76, and 62, respectively, out of 142 countries (WEF 2016, Competitiveness report).

Business sophistication is another main pillar required for making the transition to a knowledge-based economy. Our findings show that the impact of business sophistication on economic performance is both positive and significant, meaning that business sophistication can accelerate the economic growth of MENA countries. These results indicate that the knowledge workers, innovation linkages, and knowledge absorption as a subset of business sophistication are main factors for the transition towards a knowledge-based economy in this region. MENA countries have a poor status in terms of knowledge workers and knowledge absorption. For example, Kuwait, Iran, and Saudi Arabia were ranked 126, 125, and 102 out of 128 countries, respectively, for this (WIPO 2016).

The findings of this paper provide the opportunity for some policy implications regarding the knowledge-based economy and growth performance in the MENA region. The improvement in human capital and research, institutions, infrastructure, and business sophistication is important for economic growth performance in MENA countries. Thus, we can recommend for governments and policy-makers in MENA countries the following knowledge-based policies: investment in education, investment in research, reform of institutions, investment in the quantity and quality of public and private infrastructures, improving knowledge absorptive capacity, building capacity of knowledge workers, supporting policies to provide incentives for the private sector to enhance productivity, and making knowledge-related investments.

Open Access This article is distributed under the terms of the Creative Commons Attribution 4.0 International License (http://creativecommons.org/licenses/by/4.0/), which permits unrestricted use, distribution, and reproduction in any medium, provided you give appropriate credit to the original author(s) and the source, provide a link to the Creative Commons license, and indicate if changes were made.

\section{References}

Abed, G. T., \& Davoodi, H. R. (2003). Challenges of growth and globalization in the Middle East and North Africa. International Monetary Fund. Available via the Internet: http://www.imf.org/external/pubind.htm. 
Abramovitz, M. (1986). Catching up, forging ahead, and falling behind. The Journal of Economic History, 46(02), 385-406.

Abreu, M., Grinevich, V., Hughes, A., Kitson, M., \& Ternouth, P. (2008). Universities, business and knowledge exchange. University of Cambridge; Council for Industry and Higher Education. Availabe via the internet: https://eprints.soton.ac.uk.

Acemoglu, D. (2008). Introduction to modern economic growth. Princeton: Princeton University Press.

Aghion, P., \& Howitt, P. (1990). A model of growth through creative destruction (no. w3223). Cambridge: National Bureau of Economic Research.

Akcali, B. Y., \& Sismanoglu, E. (2015). Innovation and the effect of research and development (R\&D) expenditure on growth in some developing and developed countries. Procedia-Social and Behavioral Sciences, 195, 768-775.

Arellano, M., \& Bond, S. (1991). Some tests of specification for panel data: Monte Carlo evidence and an application to employment equations. The Review of Economic Studies, 58(2), 277-297.

Badinger, H., \& Tondl, G. (2003). Trade, human capital and innovation: The engines of European regional growth in the 1990s, In European regional growth (pp. 215-239). Berlin, Heidelberg: Springer.

Badinger, H., Müller, W., \& Tondl, G. (2004). Regional convergence in the European Union, 1985-1999: a spatial dynamic panel analysis. Regional Studies, 38(3), 241-253.

Balcerzak, A. P., \& Pietrzak, M. B. (2016). Quality of human capital in the European Union in the years 2004-2013, Application of structural equation modeling. Brussels.

Balkyte, A., \& Tvaronavičiene, M. (2010). Perception of competitiveness in the context of sustainable development: facets of "sustainable competitiveness". Journal of Business Economics and Management, 11(2), 341-365.

Baltagi, B. (2008). Econometric analysis of panel data. Hoboken: John Wiley \& Sons.

Banerjee, A., Duflo, E., \& Qian, N. (2012). On the road: Access to transportation infrastructure and economic growth in China (no. w17897). Cambridge: National Bureau of Economic Research.

Barro, R. J. (1991). Economic growth in a cross section of countries. The Quarterly Journal of Economics, $106(2), 407-443$.

Barro, R. J., \& Martin, X. S. I. (2004). Economic growth second edition. Cambridge: The MIT Press.

Barro, R. J., \& Sala-i-Martin, X. (1994). Quality improvements in models of growth (no. w4610). Cambridge: National Bureau of Economic Research.

Bassanini, A., Scarpetta, S., Visco, I. (2000). Knowledge technology and economic growth: recent evidence from OECD countries. National Bank of Belgium Working Paper No. 6. https://doi.org/10.2139/ Ssrn. 1705109

Bloom, D. E., Canning, D., Sevilla, J. (2002). Technological diffusion, conditional convergence, and economic growth: National Bureau of Economic Research.

Bond, S. R., Hoeffler, A., \& Temple, J. R. (2001). GMM estimation of empirical growth models, CEPR discussion paper no. 3048. London: CEPR.

Boopen, S. (2006). Transport infrastructure and economic growth: evidence from Africa using dynamic panel estimates. The Empirical Economics Letters, 5(1), 37-52.

Canning, D., \& Pedroni, P. (2004). The effect of infrastructure on long run economic growth (pp. 1-30). Harvard University. Available via the internet: https://ideas.repec.org/p/wil/wileco/2004-04.html.

Cardoso, C., \& Pentecost, E. J. (2011). Regional growth and convergence: The role of human capital in the portuguese regions. Loughborough University, Economics Discussion Paper No, 3. Loughborough.

Carlsson, B., Acs, Z. J., Audretsch, D. B., \& Braunerhjelm, P. (2009). Knowledge creation, entrepreneurship, and economic growth: a historical review. Industrial and Corporate Change, 18(6), 1193-1229.

Chapsa, X., Tsanana, E., \& Katrakilidis, C. (2015). Growth and convergence in the EU-15: more evidence from the cohesion countries. Procedia Economics and Finance, 33, 55-63.

Chen, D. H., \& Dahlman, C. J. (2005). The knowledge economy, the KAM methodology, and World Bank operations. World Bank Institute Working Paper No. 37256. Washington DC.

Christopoulos, D. K., \& Tsionas, E. G. (2004). Financial development and economic growth: evidence from panel unit root and cointegration tests. Journal of Development Economics, 73(1), 55-74.

Chun-Chien, K., \& Chih-Hai, Y. (2008). Knowledge capital and spillover on regional economic growth: evidence from China. China Economic Review, 19(4), 594-604.

Cohen, D., \& Soto, M. (2007). Growth and human capital: good data, good results. Journal of Economic Growth, 12(1), 51-76.

Cooray, A. (2009). Government expenditure, governance, and economic growth. Comparative Economic Studies, 51(3), 401-418.

Duggal, V. G., Saltzman, C., \& Klein, L. R. (2007). Infrastructure and productivity: an extension to private infrastructure and its productivity. Journal of Econometrics, 140(2), 485-502. 
Égert, B., Kozluk, T. J., \& Sutherland, D. (2009). Infrastructure and growth: empirical evidence. CESifo Working Paper Series No. 2700. Brussels.

Fagerberg, J., \& Verspagen, B. (2003). Innovation, growth and economic development: why some countries succeed and others don't. Paper presented at the Conference: Innovation Systems and development Strategies for the Third Millenium. Rio de Janeiro. Brazil.

Flachaire, E., García-Peñalosa, C., \& Konte, M. (2014). Political versus economic institutions in the growth process. Journal of Comparative Economics, 42(1), 212-229.

Fleisher, B., Li, H., \& Zhao, M. Q. (2010). Human capital, economic growth, and regional inequality in China. Journal of Development Economics, 92(2), 215-231.

Fung, M. K. (2009). Financial development and economic growth: convergence or divergence? Journal of International Money and Finance, 28(1), 56-67.

Glaeser, E. L. (2000). The new economics of urban and regional growth. The Oxford handbook of economic geography, 83-98. Oxford: Oxford University Press.

Grogan, L., \& Moers, L. (2001). Growth empirics with institutional measures for transition countries. Economic Systems, 25(4), 323-344.

Grossman, G. M., \& Helpman, E. (1994). Endogenous innovation in the theory of growth. Journal of Economic Perspectives, 8(1), 23-44.

Guellec, D., \& De La Potterie, B. V. P. (2002). R\&D and productivity growth. OECD Economic Studies, 2001(2), 103-126.

Habibullah, M. S., \& Eng, Y.-K. (2006). Does financial development cause economic growth? A panel data dynamic analysis for the Asian developing countries. Journal of the Asia Pacific Economy, 11(4), $377-$ 393.

Harris, R. G. (2001). The knowledge-based economy: intellectual origins and new economic perspectives. International Journal of Management Reviews, 3(1), 21-40.

Havrylyshyn, O., \& van Rooden, R. (2003). Institutions matter in transition, but so do policies. Comparative Economic Studies, 45(1), 2-24.

Heath, J. A. (2001). Human capital investment: an international comparison: organisation for economic cooperation and development Centre for Educational Research and Innovation, OECD, Paris, 1998, pp. 113, Price $\$ 25.00$ paperback: Pergamon.

Huallacháin, B. O. (2007). Regional growth in a knowledge-based economy. International Regional Science Review, 30(3), 221-248.

Islam, N. (2003). What have we learnt from the convergence debate? Journal of Economic Surveys, 17(3), 309-362.

Jalilian, H., Kirkpatrick, C., \& Parker, D. (2007). The impact of regulation on economic growth in developing countries: a cross-country analysis. World Development, 35(1), 87-103.

Katz, L. F., Krueger, A. B., Burtless, G., \& Dickens, W. T. (1999). The high-pressure US labor market of the 1990s. Brookings Papers on Economic Activity, 1999(1), 1-87.

Kaufmann, D., Kraay, A., \& Zoido-Lobaton, P. (1999). Governance matters, World Bank policy research working paper no. 2196. Washington, DC: World Bank.

Klasen, S. (2002). Low schooling for girls, slower growth for all? Cross-country evidence on the effect of gender inequality in education on economic development. The World Bank Economic Review, 16(3), 345373.

Kumar, B., Das, A., \& Alagirusamy, R. (2013). Study of the effect of composition and construction of material on sub-bandage pressure during dynamic loading of a limb in vitro. Biorheology, 50(1-2), 83-94.

Kurtz, M. J., \& Schrank, A. (2007). Growth and governance: models, measures, and mechanisms. Journal of Politics, 69(2), 538-554.

Lee, M.-L., Liu, B.-C., \& Wang, P. (1994). Education, human capital enhancement and economic development: comparison between Korea and Taiwan. Economics of Education Review, 13(4), 275-288.

Levy, F., \& Murnane, R. J. (1996). With what skills are computers a complement? The American Economic Review, 86(2), 258-262.

Lucas, R. E. (1988). On the mechanics of economic development. Journal of Monetary Economics, 22(1), 342.

Lucas Jr., R. E. (2015). Human capital and growth. The American Economic Review, 105(5), 85-88.

Mankiw, N. G., Romer, D., \& Weil, D. N. (1992). A contribution to the empirics of economic growth. The Quarterly Journal of Economics, 107(2), 407-437.

Miller, S. M., \& Upadhyay, M. P. (2002). Total factor productivity and the convergence hypothesis. Journal of Macroeconomics, 24(2), 267-286.

Murthy, N. V., \& Chien, I. (1997). The empirics of economic growth for OECD countries: some new findings. Economics Letters, 55(3), 425-429. 
OECD, O. (1996). The knowledge-based economy. Organisation for economic co operation and development, OECD, OECD, 2, (pp. 1-46). Paris.

Palei, T. (2015). Assessing the impact of infrastructure on economic growth and global competitiveness. Procedia Economics and Finance, 23, 168-175.

Pyöriä, P. (2005). The concept of knowledge work revisited. Journal of Knowledge Management, 9(3), 116127.

Qadri, F. S., \& Waheed, A. (2013). Human capital and economic growth: cross-country evidence from low-, middle-and high-income countries. Progress in Development Studies, 13(2), 89-104.

Raspe, O., \& Van Oort, F. (2008). Firm growth and localized knowledge externalities. Journal of Regional Analysis and Policy, 38(2), 100-116.

Roe, T. (2003). Determinants of economic growth: a cross-country empirical study. American Journal of Agricultural Economics, 85(4), 1087-1088.

Romer, P. M. (1986). Increasing returns and long-run growth. Journal of Political Economy, 94(5), 10021037.

Romer, P. M. (1990). Endogenous technological change. Journal of Political Economy, 98(5, Part 2), S71S102.

Roubini, N., \& Sala-i-Martin, X. (1995). A growth model of inflation, tax evasion, and financial repression. Journal of Monetary Economics, 35(2), 275-301.

Runiewicz-Wardyn, M. (Ed.). (2008). Knowledge-based economy as factor of competitiveness and economic growth. Warsaw: Wydawnictwa Akademickie i Profesjonalne.

Runiewicz-Wardyn, M. (2013). The role of knowledge absorption and innovation capability in the technological change and economic growth of EU regions. International Journal of Management and Economics, 39(1), 51-69.

Sab, R., \& Smith, S. C. (2001). Human capital convergence: International evidence (no. 2001-2032). Washington, D.C.: International Monetary Fund.

Sala-i-Martin, X. X. (1996). Regional cohesion: evidence and theories of regional growth and convergence. European Economic Review, 40(6), 1325-1352.

Sala-i-Martin, X. X., \& Barro, R. J. (1995). Technological diffusion, convergence, and growth (No. 735). Center Discussion Paper. http://hdl.handle.net/10419/160652

Santos, L. A., \& Barrios, E. B. (2011). Small sample estimation in dynamic panel data models: a simulation study. Open Journal of Statistics, 1(02), 58.

Schultz, T. P. (2007). Population policies, fertility, women's human capital, and child quality. Handbook of Development Economics, 4, 3249-3303.

Slesman, L., Baharumshah, A. Z., \& Ra'ees, W. (2015). Institutional infrastructure and economic growth in member countries of the Organization of Islamic Cooperation (OIC). Economic Modelling, 51, 214-226.

Solow, R. M. (1956). A contribution to the theory of economic growth. The Quarterly Journal of Economics, $70(1), 65-94$.

Swan, T. W. (1956). Economic growth and capital accumulation. Economic record, 32(2), 334-361.

Torero, M., Chowdhury, S., \& Bedi, A. S. (2002). Telecommunications infrastructure and economic growth: A cross-country analysis. Information and communication technologies for development and poverty reduction, 21-63. Baltimore: Johns Hopkins University Press.

Verbeek, M. (2008). A guide to modern econometrics. Chichester: John Wiley \& Sons.

Wintjes, R., \& Hollanders, H. (2010). The regional impact of technological change in 2020. Report to the European Commission. Brussels.

WIPO (2016). The global innovation index 2016.www.wipo.int/edocs/pubdoecs/en/.

Wolf, A. (2002). Does education matter? Myths about education and economic growth. Perspectives, 6(4), $115-118$.

World Bank. (2007). Building knowledge economies: Advanced strategies for development. Washington, DC: World Bank.

World Bank (2016). Middle East and North Africa overview. www.worldbank.org/en/region/mena/. 